\title{
Developmental Expression Pattern of Phototransduction Components in Mammalian Pineal Implies a Light-Sensing Function
}

\author{
Seth Blackshaw and Solomon H. Snyder \\ Johns Hopkins University School of Medicine, Departments of Neuroscience, Pharmacology and Molecular Sciences, \\ and Psychiatry, Baltimore, Maryland 21205
}

\begin{abstract}
Whereas the pineal organs of lower vertebrates have been shown to be photosensitive, photic regulation of pineal function in adult mammals is thought be mediated entirely by retinal photoreceptors. Extraretinal regulation of pineal function has been reported in neonatal rodents, although both the site and molecular basis of extraretinal photoreception have remained obscure. In this study we examine the developmental expression pattern of all of the principal components of retinal phototransduction in rat pineal via cRNA in situ hybridization. All of the components needed to reconstitute a functional phototransduction pathway are expressed in the majority of neonatal
\end{abstract}

pinealocytes, although the expression levels of many of these genes decline dramatically during development. These findings strongly support the theory that the neonatal rat pineal itself is photosensitive. In addition, we observe in neonatal pinealocytes the expression of both rod-specific and cone-specific phototransduction components, implying the existence of functionally different subtypes of pinealocytes that express varying combinations of phototransduction enzymes.

Key words: pineal; phototransduction; opsin; transducin; phosphodiesterase; rhodopsin kinase; arrestin; recoverin; IRBP; extraretinal; rat; development; in situ hybridization
There is abundant evidence for extraretinal photoreception in lower vertebrates. Photoreception has been demonstrated for areas of the diencephalon (Hartwig and Oksche, 1982), the iris (Barr, 1989), melanophores (Weber, 1983), and the pineal complex (Oksche, 1965; Wurtman et al., 1968; Eakin, 1973). The most extensive studies have been conducted for the pineal complex, which includes the pineal organ proper and the parapineal organ (in fish, lampreys, and salamanders) and which in frogs and lizards becomes a full-fledged parietal eye. In lampreys (Meissl et al., 1982; Morita et al., 1985, 1989), fish (Dodt, 1963; Tabata et al., 1975; Meissl et al., 1986; Marchiafava and Kusmic, 1993), frogs (Dodt and Heerd, 1962; Morita and Dodt, 1973), and lizards (Dodt and Scherer, 1968; Solessio and Engbretson, 1993), electrophysiological responses to light occur in the pineal and/or parapineal. In the chicken pineal in organ culture, light exposure directly regulates circadian variations in melatonin synthesis (Deguchi, 1982a), and extraretinal photoreceptors have been shown to play a role in a variety of physiological and endocrine processes (Menaker and Keatts, 1968; Menaker et al., 1970). A pineal-specific opsin, pinopsin, has been cloned from chicken pineal (Okano et al., 1994; Max et al., 1995), and a parapinealspecific opsin has been cloned from catfish (Blackshaw and Snyder, 1997).

In contrast to the strong evidence for pineal phototransduction in lower vertebrates, studies on mammalian pineal photosensitivity are much more limited. Axelrod and associates (Zweig et al.,

\footnotetext{
Received June 4, 1997; accepted Aug. 8, 1997.

This work was supported by United States Public Health Service Grant DA-00266 and Research Scientist Award DA-00074 to S.H.S. S.B. was a Howard Hughes Medical Institute predoctoral fellow. We thank R. Vassar and R. Axel for assistance with in situ hybridization, H. Sun for making the initial observation of blue cone pigment expression in adult mouse pineal, R. Adler for the gift of the mouse IRBP cDNA, and J. Nathans and K.-W. Yau for helpful discussions.

Correspondence should be addressed to Dr. Solomon H. Snyder, Johns Hopkins University School of Medicine, Department of Neuroscience, 725 North Wolfe Street, Baltimore, MD 21205.

Copyright (C) 1997 Society for Neuroscience $\quad 0270-6474 / 97 / 178074-09 \$ 05.00 / 0$
}

1966) demonstrated light-induced regulation of pineal gland serotonin levels in neonatal rats in whom the eyes had been removed. In replicating these findings, Yuwiler and colleagues (Wetterberg et al., 1970; Ulrich et al., 1973) suggested that the Harderian gland is the light-sensitive organ that influences the pineal gland, although Sakai (1981) suggested that removal of the Harderian gland may have affected pineal function indirectly. Sympathectomy of neonatal pineal preserves light entrainment of pineal function in the first few weeks of life, whereas sympathectomy at later developmental stages effectively abolishes light entrainment, implying that neonatal pineal might be photosensitive (Machado et al., 1969a,b). Findings that neonatal pinealocytes show photoreceptor-like differentiation in vivo (Zimmerman and Tso, 1975) and in vitro (Araki, 1992) favor direct detection of light by neonatal rat pineal. Regulation of the melatonin-forming enzyme serotonin $N$-acetyltransferase (NAT) has been demonstrated in blinded neonatal rats in some studies (Torres and Lytle, 1990), but not in others (Deguchi, 1982b; Reppert et al., 1984). It has not proved feasible to demonstrate light-induced electrophysiological changes in dissociated rat pinealocytes nor modulation of melatonin production in neonatal pineal cultures (Brammer and Binkley, 1981).

Phototransduction capacity also can be examined by monitoring molecular components of the phototransduction pathway. Individual studies of mammalian pineal have examined only a few elements of the phototransduction cascade (Korf, 1994). Rhodopsin immunoreactivity and mRNA, detected by reverse transcription-PCR (RT-PCR), show considerable species-specific differences in pattern and levels of expression (Korf et al., 1985a; Vigh-Teichmann et al., 1986; Foster et al., 1989; Araki, 1992; Huang et al., 1992; Kramm et al., 1993; Zhao et al., 1997). Substantial rod transducin immunoreactivity has been observed in the pineal of many lower vertebrates, but not in rat pineal (van Veen et al., 1986a). Biochemical evidence suggests the presence of cone cyclic GMP phosphodiesterase, particularly in rat neona- 
tal rat pineal (Caracamo et al., 1995). Both rod-type and conetype cyclic nucleotide-gated channels have been reported in bovine pineal via RT-PCR (Distler et al., 1994), and cone-type channels have been reported in bovine pineal by immunohistochemical techniques (Bonigk et al., 1996). Rhodopsin kinase and rod arrestin have been detected in mammalian pineal, but it has been suggested that they mediate phosphorylation of $\beta$ adrenergic receptors related to phototransduction (Sommers and Klein, 1984; Korf et al., 1985b, 1986; Ho et al., 1986; Adamus et al., 1989; Craft et al., 1990; Palczewski et al., 1990).

To investigate possible phototransduction in the pineal gland, we have conducted in situ hybridization studies of a large number of elements of the pathway. We have looked at various developmental stages, because the bulk of the evidence had suggested that, if present, mammalian pineal phototransduction would predominate at earlier developmental stages. We now report the expression of a sufficient number of components of the photosensory pathway in rat pineal to reconstitute a complete phototransduction pathway. Most striking is the high density of cone-specific elements, particularly in neonatal pineal.

\section{MATERIALS AND METHODS}

In situ hybridization. The probes used for in situ hybridization were digoxigenin cRNA probes synthesized from cDNAs in pBluescript KS, while rhodopsin and rod and cone transducin cRNAs were obtained from cDNAs subcloned into the pCR vector (Invitrogen). DNA for probe synthesis was prepared by Perfect Prep (5 Prime $\rightarrow 3$ Prime, Boulder, $\mathrm{CO}$ ), digested with appropriate enzymes, checked for completeness of digestion on minigel, and then protease K-digested, phenol/chloroformextracted four times, chloroform-extracted two times, and collected via ethanol precipitation. Probes were synthesized with T3 or T7 polymerase, checked on denaturing gels, and purified via $\mathrm{LiCl}$ precipitation. We used the in situ hybridization protocol method of Schaeren-Wiemers and Gerfin-Moser (1993) with the following modifications: Sprague Dawley rats and C57/B6 mice kept on a 12:12 light-dark cycle were decapitated in the early afternoon (2-4 P.M.). Then tissue samples were embedded and frozen at $-80^{\circ} \mathrm{C}$ until use. Ten micrometer sections were cut onto Superfrost Plus slides (Fisher Scientific, Pittsburgh, PA). All sections that were used through the hybridization step were DEPC-treated and RNase-free. Sections were post-fixed for $5 \mathrm{~min}$ in $4 \%$ paraformaldehyde/ PBS, washed three times for $3 \mathrm{~min}$ in PBS, acetylated for $10 \mathrm{~min}$ in 0.1 $\mathrm{M}$ triethanolamine, $\mathrm{pH} 8.0$, and $0.25 \%$ acetic anhydride, washed three times for $3 \mathrm{~min}$ in PBS, and prehybridized for 2-6 hr in hybridization buffer containing $50 \%$ formamide, $5 \times$ SSC, $5 \times$ Denhardt's solution, 500 $\mu \mathrm{g} / \mathrm{ml}$ sonicated, denatured herring sperm DNA, and $250 \mu \mathrm{g} / \mathrm{ml}$ E. coli MRE 600 tRNA. Then this buffer was removed, and $0.1 \mathrm{ml}$ of fresh buffer containing 30-40 ng of probe was added to the slide, covered with a siliconized coverslip, and hybridized overnight at $72^{\circ} \mathrm{C}$. Coverslips were removed by soaking in $5 \times \mathrm{SSC}$ at $72^{\circ} \mathrm{C}$; then slides were washed two times for $1 \mathrm{hr}$ in $0.2 \times \mathrm{SSC}$ at $72^{\circ} \mathrm{C}$. Sections were washed for $5 \mathrm{~min}$ in $0.2 \times \mathrm{SSC}$ at room temperature and for $5 \mathrm{~min}$ in TBS and then blocked for $1 \mathrm{hr}$ at room temperature in 5\% heat-inactivated normal goat serum in TBS. Slides were incubated overnight in this solution containing a 1:5000 dilution of sheep anti-digoxigenin Fab fragments conjugated to alkaline phosphatase. On the next day the slides were washed three times for $5 \mathrm{~min}$ in TBS and one time for $5 \mathrm{~min}$ in alkaline phosphatase buffer containing $0.1 \mathrm{M}$ Tris, $\mathrm{pH} 9.5,0.1 \mathrm{M} \mathrm{NaCl}$, and $50 \mathrm{mM} \mathrm{MgCl}_{2}$. Then slides were placed in light-tight boxes; $1-2 \mathrm{ml}$ of color development solution, containing $3.375 \mu \mathrm{g} / \mathrm{ml}$ nitroblue tetrazolium, $3.5 \mu \mathrm{g} / \mathrm{ml}$ 5-bromo-4chloro-3-indoyl-phosphate (BCIP), and $0.24 \mathrm{mg} / \mathrm{ml}$ levamisole, was placed on the slide. The color reaction was allowed to run from $30 \mathrm{~min}$ (for rhodopsin in the retina) to $2 \mathrm{~d}$ (for most other probes in both retina and pineal) at room temperature. The reaction was stopped in Tris/ EDTA buffer and $\mathrm{ddH}_{2} 0$, and the slides were sealed in Aquapolymount (Polysciences, Warrington, PA).

The probes that we used were mostly a mixture of rat and mouse cDNAs. Where possible, the rat form of the gene being tested was obtained, but in cases in which a rat orthologue had not been identified, the mouse isoform was used. In these cases both the retina and pineal of the adult mouse were tested with the probe to confirm their specificity. In two cases, those of the cone isoforms of retinal phosphodiesterase and the cyclic nucleotide-gated channel, highly conserved regions of the human isoforms of these genes were chosen as probes, because rodent orthologues of these genes have not yet been cloned. With the exception of mouse red cone pigment and mouse blue cone pigment, which were kind gifts from Dr. Jeremy Nathans (Johns Hopkins University School of Medicine), the templates to generate all of the probes used in this study were obtained by RT-PCR from retina cDNA, with sequences being confirmed by automatic DNA sequencing. The exact regions covered by each probe, and the reference for the original cloning and the base pair numbering used, are as follows: rat rhodopsin, 17-749 bp (Barnstable and Morabito, 1994); mouse blue cone pigment, full-length cDNA (J. Nathans, unpublished data); mouse red cone pigment, full-length cDNA (J. Nathans, unpublished data); mouse rod transducin, 98 bp (exon 4) and 33 bp (exon 8) (Raport et al., 1989); mouse cone transducin, 84-794 bp (Zigman et al., 1994); mouse rod phosphodiesterase, 1714-2294 bp (Baehr et al., 1991); human cone phosphodiesterase, 1826-2358 bp (Viczian et al., 1995); rat rod cyclic nucleotide-gated channel, 644-1370 bp (Wei et al., 1996); human cone cyclic nucleotide-gated channel, 944-1645 bp (Yu et al., 1996); mouse recoverin, 23-883 bp (McGinnis et al., 1992); rat rhodopsin kinase, 125-1044 bp (Zhao et al., 1997); rat rod arrestin, 182-1047 bp (Craft et al., 1990); rat cone arrestin, 28-291 bp (Craft et al., 1994); and mouse interphotoreceptor retinol-binding protein (IRBP), 1802-2161 bp (R. Adler, unpublished data).

To ascertain probe specificity, we synthesized sense control probes for each of these transcripts and tested them on pineal and retina sections. No specific hybridization was detected with any of the sense control probes. Moreover, in sections of embryonic day 18 rat embryos tested with each probe, no specific hybridization was seen.

\section{RESULTS \\ Visual pigments}

We detected rhodopsin expression in virtually all pinealocytes, with the highest levels at postnatal day 2 (P2) (Fig. 1A). Levels remained high until $\mathrm{P} 12$ and then declined rapidly, with very low levels present between P16 and P200. Absolute rhodopsin mRNA levels were substantially less in the pineal than in the retina. Thus, comparable levels of staining were observed in the P2 pineal gland exposed for $3 \mathrm{~d}$ and the rat retina exposed for $30 \mathrm{~min}$. Whereas very little rhodopsin mRNA was evident in adult rat pineal, we observed substantial staining in adult mouse pineal, which fits with immunohistochemical evidence for rhodopsin protein in adult mouse, but not rat, pineal (Araki, 1992; Kramm et al., 1993).

In contrast to the low levels of rhodopsin in rat pineal, blue cone pigment expression is as high in the pineal as in the retina (Fig. $1 B$ ), which accords with the recent cloning of a cDNA encoding the rat blue cone pigment from a rat pineal cDNA library (Zhao et al., 1997). Unlike the decline with age in pineal rhodopsin, blue cone pigment expression remains fairly constant between P2 and P200. Individual pinealocytes vary in expression of blue cone pigment, with $\sim 5 \%$ demonstrating very high levels of expression, comparable to those of retinal blue cones. With $2 \mathrm{~d}$ exposure and high magnification, almost all pinealocytes display some level of blue cone pigment, but only $\sim 5 \%$ manifest uniquely high levels. Because the probe used for blue cone pigment comes from the mouse, we compared mouse and rat pineal and observed similar levels of expression.

In striking contrast to the substantial levels of blue cone pigment, we detected virtually no red cone pigment in rat or mouse pineal gland despite robust expression in the retina (Fig. 1C).

\section{Transducin}

Rod transducin is detectable in the pineal only at P12 in a small subset of cells in the superficial layer of the rostral tip of the pineal gland (Fig. 2A). Interestingly, in the retina, expression of rod transducin is first detectable at $\mathrm{P} 12$ at the same exposure time (data not shown) but then increases to high adult levels. Our 
A
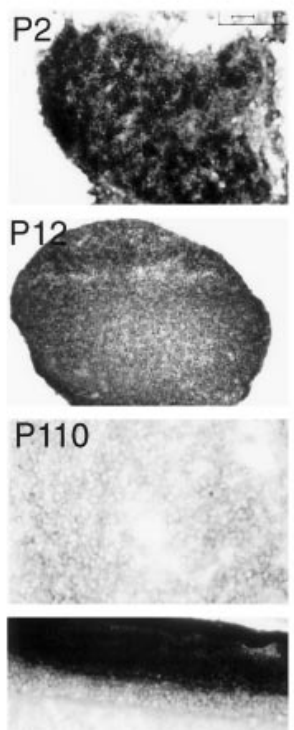

mouse retina

C
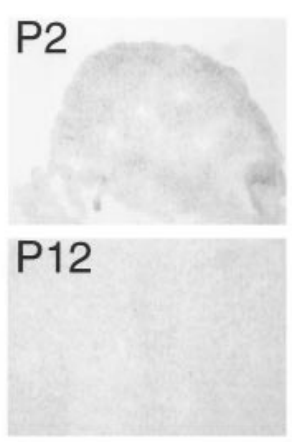

mouse pineal

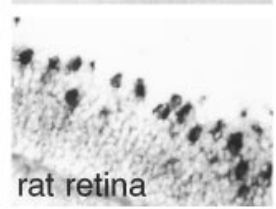

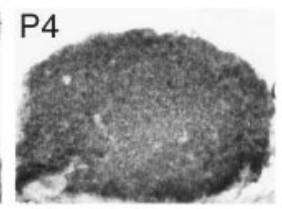
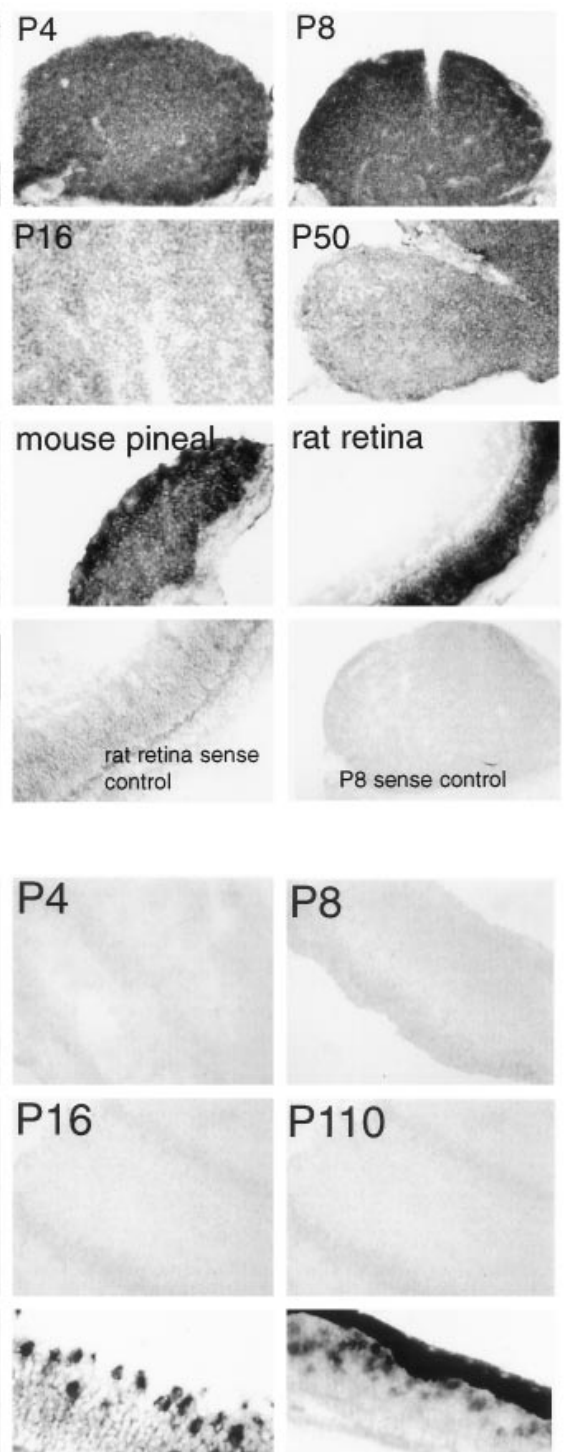

mouse retina

findings are in agreement with previous immunohistochemical studies that report no rod transducin immunoreactivity in adult mammalian pineal (van Veen et al., 1986a).

In contrast to the negligible levels of rod transducin, cone transducin expression is extremely robust (Fig. 2B)-much higher in the pineal than in the retina, using identical exposure times. Expression is so high in the pineal from P2-P16 that we cannot determine reliably any variation in expression levels. After P16 there is some decline, although substantial levels are evident in the adult pineal. Adult mouse pineal also expresses cone transducin.

\section{Phosphodiesterase and cyclic} nucleotide-gated channel

Negligible levels of rod phosphodiesterase are evident throughout development except in a small subset of cells in the P12 rat pineal (Fig. 3A). The subset of cells expressing rod phosphodiesterase at P12 displays the same localization as the cells expressing rod transducin at P12. On the other hand, the pineal displays very high levels of cone phosphodiesterase, greater than cone photo-

B
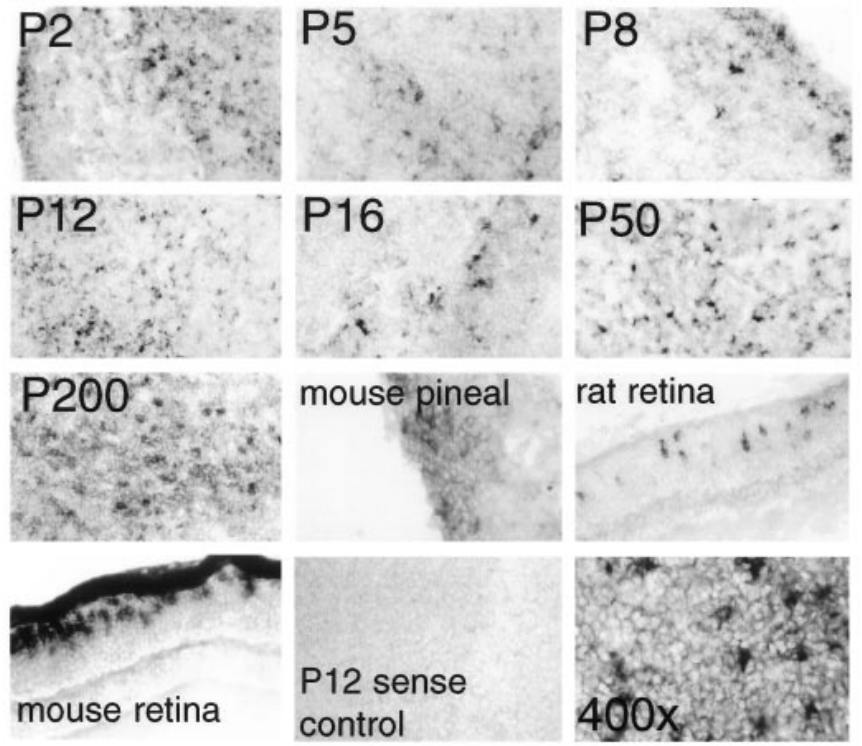

Figure 1. Expression of visual pigment mRNA in rodent pineal at different ages. $A$, Rhodopsin. Rat rhodopsin is used as a probe. All magnifications are at $100 \times$ except $\mathrm{P} 2$ rat pineal, adult mouse pineal, adult rat retina, and adult mouse retina, which are at $200 \times$. Exposure times for adult rat and mouse retina are $30 \mathrm{~min}$, whereas exposure times for pineals are $2 \mathrm{~d}$. Exposure times for both sense controls are $2 \mathrm{~d}$. $B$, Blue cone pigment. Mouse blue cone pigment is used as a probe. All magnifications are at $100 \times$ except $\mathrm{P} 2$ rat pineal, adult mouse pineal, adult rat retina, and adult mouse retina, which are at $200 \times$. The dark band above the photoreceptor layer of the mouse retina in this and all subsequent figures is the retina pigmented epithelium, which is unpigmented in the albino rat retinas tested. The final panel, showing P200, is taken at $400 \times$ magnification. $C$, Red cone pigment. Mouse red/green cone pigment is used as a probe. All magnifications are at $100 \times$ except $\mathrm{P} 2$ rat pineal, adult mouse pineal, adult rat retina, and adult mouse retina, which are at $200 \times$.

receptors of the retina, with expression evident in the majority of pinealocytes (Fig. 3B). Peak levels at P8 decline to substantially lower adult values. Previously published biochemical assays $(\mathrm{Ca}-$ racamo et al., 1995) also observed cone, but not rod, phosphodiesterase in rat pineal, with high levels at P10 and approximately fivefold lower levels at P50.

We have failed to detect expression of cyclic nucleotide channels in the rat pineal at any time point between P2 and P110 (data not shown). For the rod channel we used a cRNA probe derived from the rat sequence, which gives robust staining in the retina. Our failure to observe rod-specific channel expression is in line with immunohistochemical data from bovine pineal, which indicate that no rod channel is expressed in pinealocytes (Bonigk et al., 1996), but is at odds with a recently published study (Ding et al., 1997) claiming widespread expression of the rod channel in pineal and nonsensory tissues. The cone channel has not been cloned from rodents. Using a probe derived from a highly conserved region of the human cone channel, we did not detect expression in either rat retina or pineal at any developmental 
A
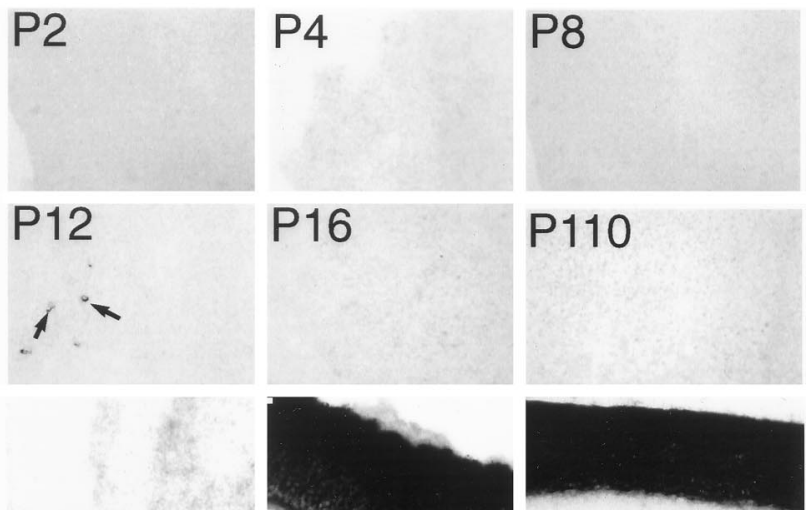

mouse pineal
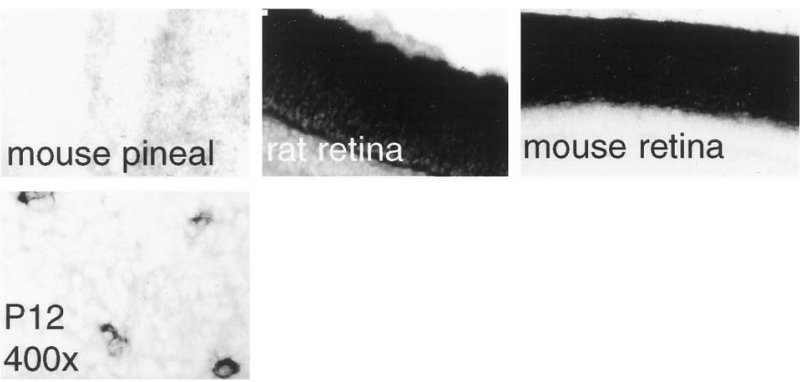

B
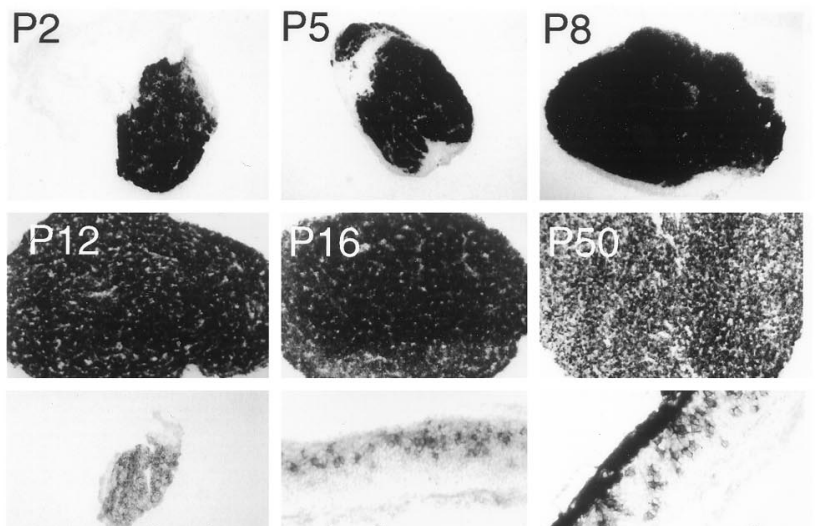

mouse pineal
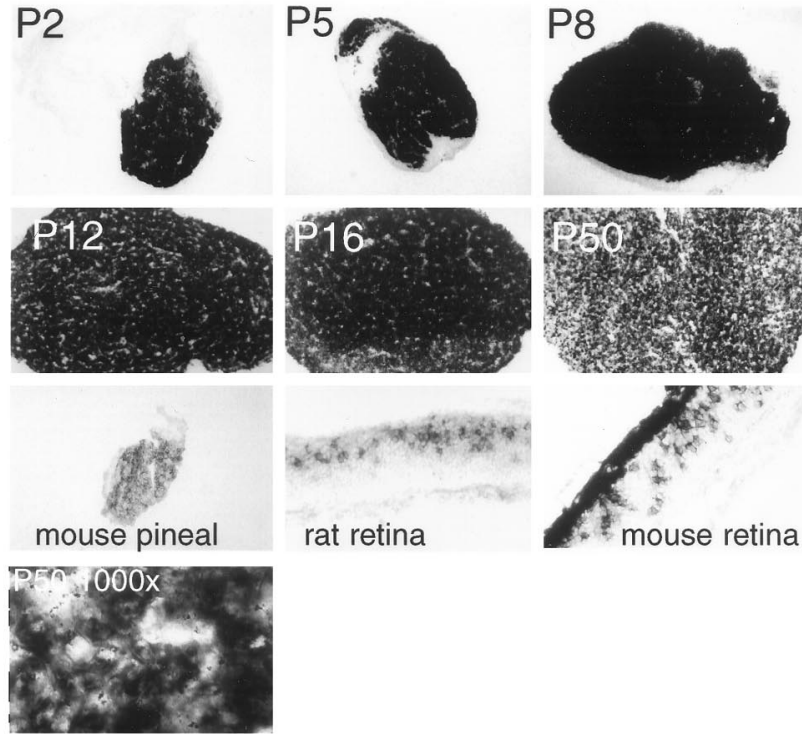

rat retina

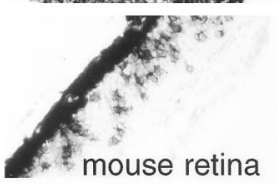

Figure 2. Transducin expression in rodent pineal at different ages. $A$, Rod transducin. Mouse rod transducin is used as a probe. All magnifications are at $100 \times$ except adult mouse pineal, adult rat retina, and adult mouse retina, which are at $200 \times$. The final panel, showing P12 rat pineal, is taken at $400 \times$ magnification. Black arrows indicate selected rod transducin-expressing cells in the P12 pineal. $B$, Cone transducin. Mouse cone transducin is used as a probe. All magnifications are at $100 \times$ except adult mouse pineal, adult rat retina, and adult mouse retina, which are at $200 \times$. The final panel, showing P200 rat pineal, is taken at $400 \times$ magnification. Note the nonexpressing meninginal tissue that surrounds the P2-P8 pineals.

stage. Because we do not know the degree of sequence conservation between human and rat, we can draw no conclusion regarding the expression of this channel in rat pineal.

\section{Desensitization elements}

Rhodopsin kinase is expressed in the majority of pinealocytes at all developmental stages, with no pronounced alterations between P2 and P110 (Fig. 4A). A subset of pinealocytes, which occur in

A

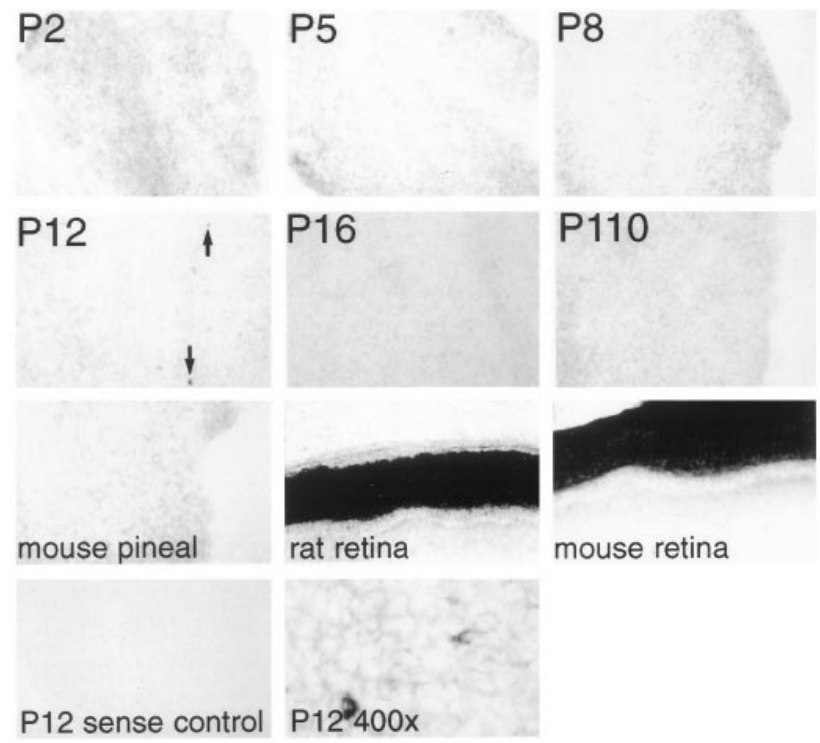

B
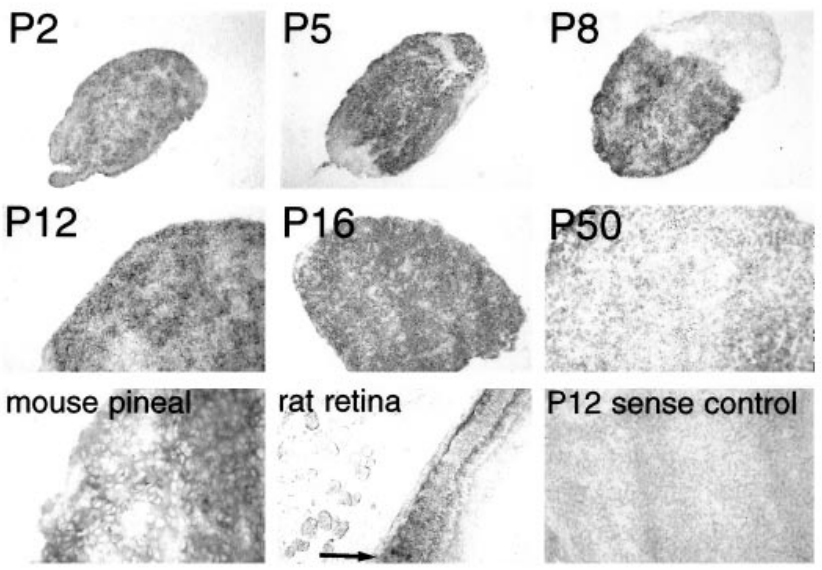

Figure 3. Expression of phosphodiesterase in rodent pineal at different ages. $A$, Rod phosphodiesterase. Mouse rod phosphodiesterase is used as a probe. All magnifications are at $100 \times$ except adult mouse pineal, adult rat retina, and adult mouse retina, which are at $200 \times$. The final panel, showing P12 rat pineal, is taken at $400 \times$ magnification. Black arrows indicate selected rod phosphodiesterase-expressing cells in the P12 pineal. $B$, Cone phosphodiesterase. Human cone phosphodiesterase is used as a probe. All magnifications are at $100 \times$ except adult mouse pineal, adult rat retina, and adult mouse retina, which are at $200 \times$. Note the nonexpressing meninginal tissue that surrounds the P2-P12 pineals. The arrow points out selected, weakly hybridizing cone photoreceptor cells.

circular clusters, displays much more intense expression than the majority of pinealocytes. Although substantial, pineal levels of rhodopsin kinase are markedly less than those of the retina, which agrees with reported developmental variations in pineal rhodopsin kinase activity (Ho et al., 1986).

We detected considerably less expression of recoverin than rhodopsin kinase. Recoverin levels are very low at birth, peak at P5, and then decline to low adult levels (Fig. 4B). Even at P5, only $\sim 1-2 \%$ of cells express recoverin. This, too, is in general agreement with immunohistochemical studies of recoverin immunoreactivity in pineal (Korf et al., 1992), although previous studies reported recoverin-expressing cells to be found predominantly in 
A

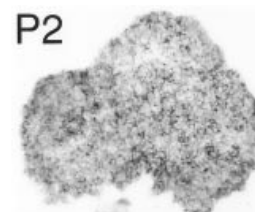

P12
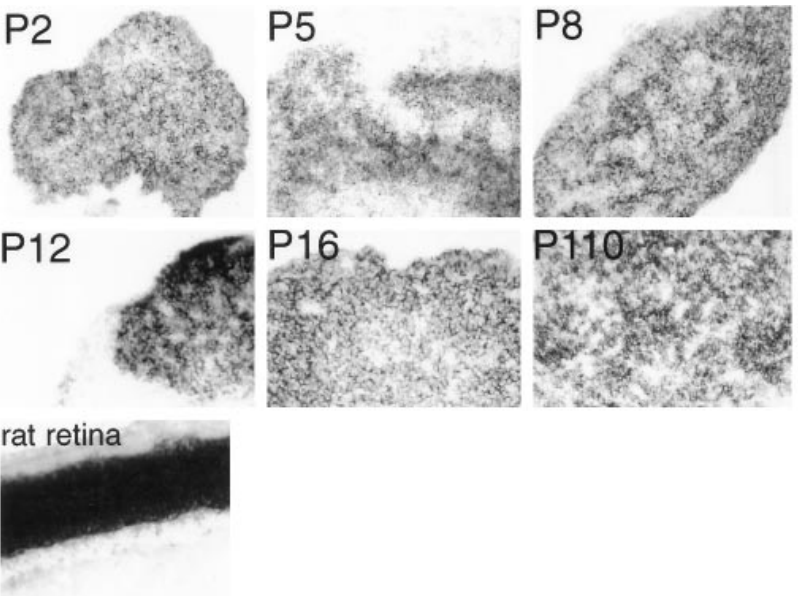

B
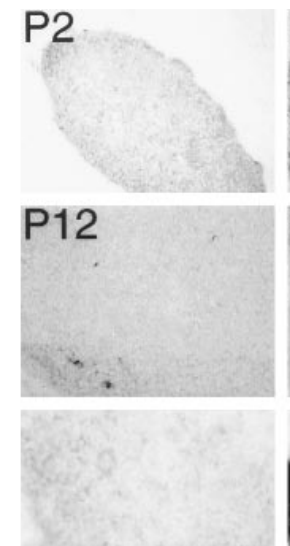

mouse pineal
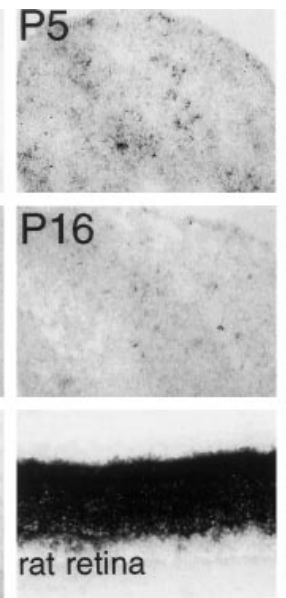
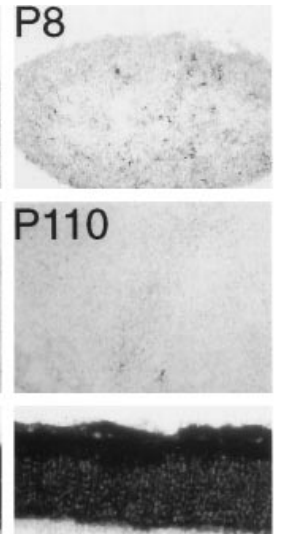

mouse retina
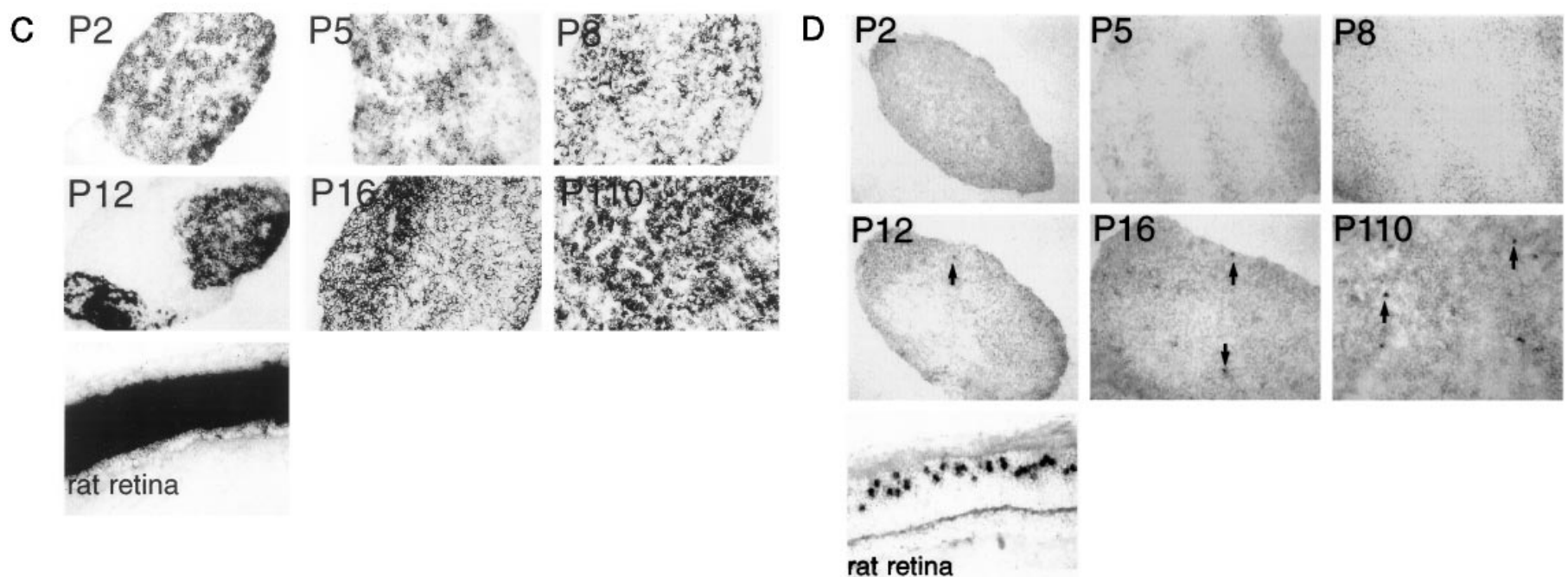

Figure 4. Phototransduction desensitization elements expressed in rodent pineal at different ages. $A$, Rhodopsin kinase. Rat rhodopsin kinase is used as a probe. All magnifications are at $100 \times$ except adult rat retina, which is at $200 \times$. Note the nonexpressing meninginal tissue adjacent to the P12 pineal. $B$, Expression of recoverin. Mouse recoverin is used as a probe. All magnifications are at $100 \times$ except adult mouse pineal, adult rat retina, and adult mouse retina, which are at $200 \times$. $C$, Rod arrestin. Rat rod arrestin is used as a probe. All magnifications are at $100 \times$ except adult rat retina, which is at $200 \times$. Note the nonexpressing meninginal tissue adjacent to the P12 pineal. D, Cone arrestin. Rat cone arrestin is used as a probe. All magnifications are at $100 \times$ except adult rat retina, which is at $200 \times$. Arrows indicate selected cone arrestin-expressing cells.

the pineal cortex, and we observe recoverin-positive cells in both superficial and deep layers of the pineal. Given the fact that recoverin is a putatively specific negative regulator of rhodopsin kinase activity (Calvert et al., 1995), this mismatch in expression is striking. The recoverin expression in selected cells of the inner nuclear layer is in accordance with immunohistochemical work demonstrating recoverin expression in cone bipolar cells of the mammalian retina (Milam et al., 1993).

Rod arrestin is expressed robustly in the majority of pinealocytes, with levels fairly similar between P2 and P110 (Fig. 4C). Highly expressing rod arrestin cells occur in clusters, with a disposition very similar to that of rhodopsin kinase and resembling that seen in previous immunohistochemical work (Korf et al., 1985b, 1986). By contrast, cone arrestin expression is quite limited, with only $0.5-1.0 \%$ of cells displaying cone arrestin beginning at P12 and gradually increasing to P110 (Fig. 4D). Another group (Craft et al., 1994), using in situ hybridization, also detected cone arrestin in a small subset of pinealocytes in the adult rat.

\section{Interphotoreceptor retinoid-binding protein (IRBP)}

IRBP is a small protein, a member of the lipocalin family, which transports retinol from the retinal pigmented epithelium to the photoreceptors (Pepperberg et al., 1993). Robust IRBP expression is evident in the majority of pinealocytes, peaking at P5-P8 and declining to substantially lower levels in the adult (Fig. 5). Neonatal levels of pineal IRBP are comparable to those of the retina. High levels of IRBP expression are evident in the adult mouse pineal. In situ hybridization of adult bovine pineal also has detected IRBP in a subset of cells (van Veen et al., 1986b), as has immunohistochemical analysis of adult rodent, monkey, and cow pineal (Rodrigues et al., 1986; Bridges et al., 1987).

\section{Other potential sites of extraretinal photoreception}

Although most evidence suggests that light reaches the neonatal pineal gland directly through the skull, Wetterberg et al. (1970) suggested that the Harderian gland is the light sensor that conveys light information to the neonatal pineal. We conducted in situ 


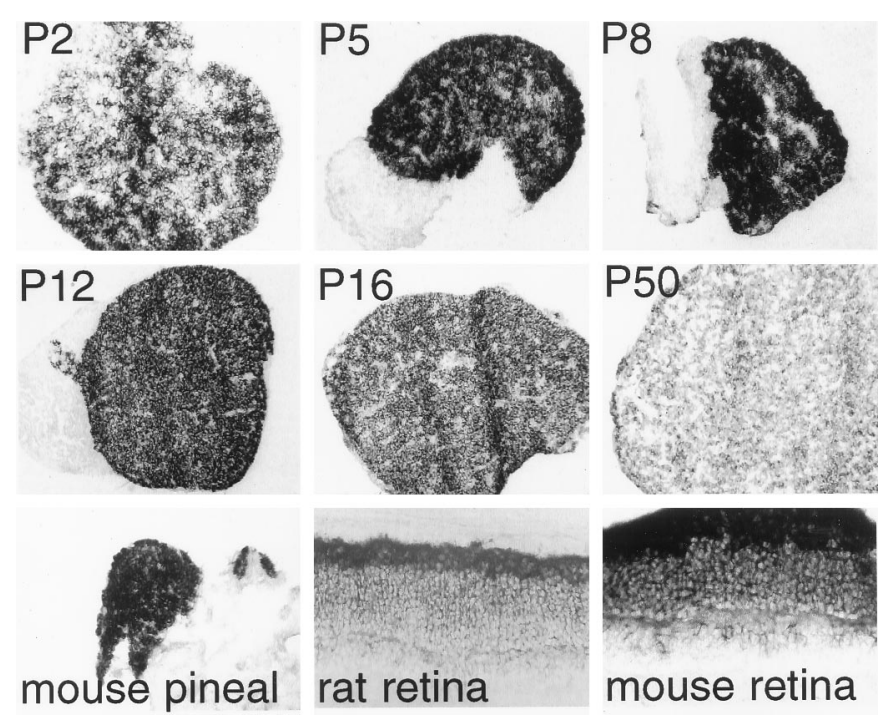

Figure 5. Expression of interphotoreceptor retinol-binding protein (IRBP) in rodent pineal at different ages. Mouse IRBP is used as a probe. All magnifications are at $100 \times$ except $\mathrm{P} 2$ rat pineal, adult mouse pineal, adult rat retina, and adult mouse retina, which are at $200 \times$.

hybridization of the P12 rat Harderian gland for all of the phototransductive elements described here and detected no expression of any of the transcripts tested (data not shown).

\section{DISCUSSION}

The main finding of this study is that the principal components needed to reconstitute a functional phototransduction pathway are present in the majority of mammalian pinealocytes and that

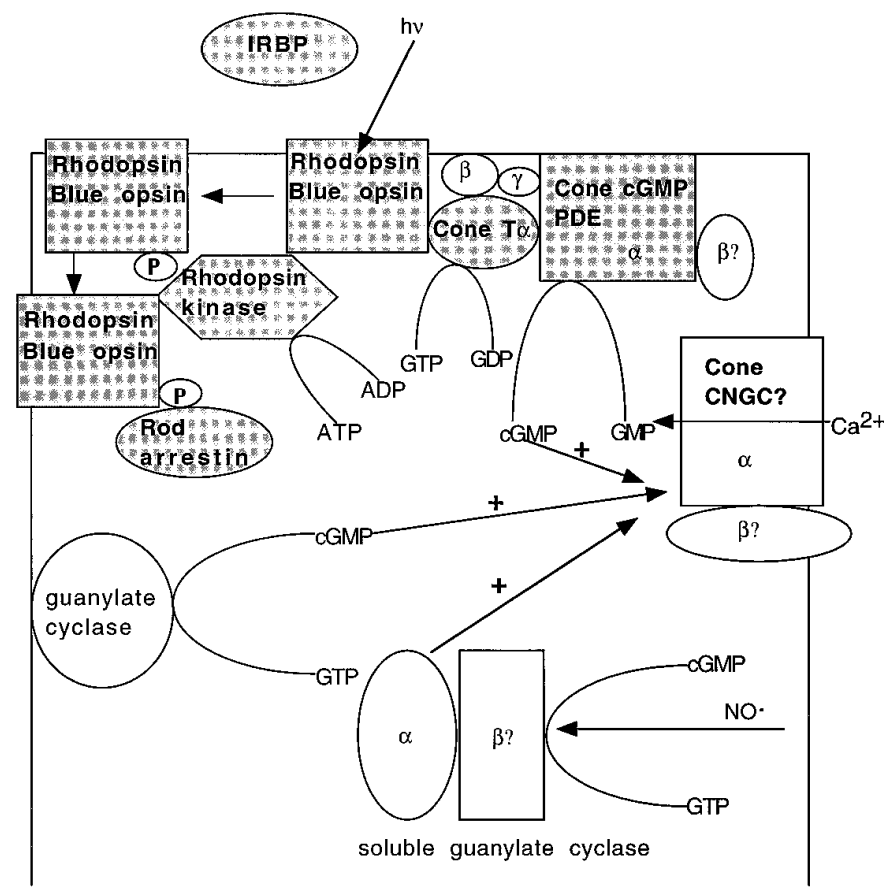

Figure 6. Potential mechanisms of phototransduction in neonatal rodent pineal. Shaded phototransduction components are expressed in the majority of neonatal rat pinealocytes and together can form a complete phototransduction cascade. Membrane-linked and soluble NO-activated guanylate cyclase, shown as potential sources of cGMP, have been shown to be expressed in rat pinealocytes by numerous studies (Spessert, 1993; Lin et al., 1994; Maronde, 1995; Yang et al., 1995).

\begin{tabular}{|c|c|c|c|}
\hline $\begin{array}{l}\text { Phototransduction } \\
\text { components }\end{array}$ & $\begin{array}{l}\text { Percentage of cells } \\
\text { expressing }\end{array}$ & $\begin{array}{l}\text { Developmental time } \\
\text { course }\end{array}$ & Expression levels \\
\hline Rhodopsin & $>80$ & $\begin{array}{l}\text { High P2-P8, } \\
\quad>20 \times \text { lower in adult }\end{array}$ & $\begin{array}{l}++++\mathrm{P} 2-\mathrm{P} 8 \\
++\mathrm{P} 12-\mathrm{P} 16 \\
+/-\mathrm{P} 60\end{array}$ \\
\hline Cone transducin & $>80$ & High P2-P8 & $++++\mathrm{P} 2-\mathrm{P} 8$ \\
\hline Cone phosphodiesterase IRBP & & $5-10 \times$ lower in adult & $\begin{array}{l}+++\mathrm{P} 12-\mathrm{P} 16 \\
+/++\mathrm{P} 110\end{array}$ \\
\hline $\begin{array}{l}\text { Rhodopsin kinase } \\
\text { Rod arrestin }\end{array}$ & $>80$ & High P2-P110 & $\begin{array}{l}++ \text { Most cells } \\
++++ \text { Some cells }\end{array}$ \\
\hline Blue cone pigment & $\begin{array}{l}5-10 \\
\quad(\text { low in }>50 \%)\end{array}$ & High P2-P110 & $\begin{array}{l}+++ \\
+/- \text { In many cells }\end{array}$ \\
\hline $\begin{array}{l}\text { Rod transducin } \\
\text { Rod phosphodiesterase }\end{array}$ & $<0.2$ & Only seen at $\mathrm{P} 12$ & +++ \\
\hline Recoverin & $0.3-2$ & $\begin{array}{l}\text { Low at P2 } \\
\text { High at P5 } \\
\text { Gradually lower P8-P16 } \\
\text { Low in adult }\end{array}$ & $\begin{array}{l}+\mathrm{P} 2 \\
+++\mathrm{P} 5 \\
++\mathrm{P} 8-\mathrm{P} 16 \\
+\mathrm{P} 110\end{array}$ \\
\hline Cone arrestin & $0.2-1$ & $\begin{array}{l}\text { Low at P12 } \\
\text { Higher at P16 } \\
\text { High at P110 }\end{array}$ & $\begin{array}{l}-\mathrm{P} 2-\mathrm{P} 8 \\
+/-\mathrm{P} 12 \\
+\mathrm{P} 16 \\
++\mathrm{P} 110\end{array}$ \\
\hline Red cone pigment & 0 & None & $-\mathrm{P} 2-\mathrm{P} 110$ \\
\hline
\end{tabular}

Rod cyclic nucleotide-gated channel 
many of these are expressed at high levels in neonatal animals but at low levels in adults (Table 1; Fig. 6). Cone-related elementssuch as the blue cone pigment, cone transducin, and cone phosphodiesterase-are expressed most robustly, with levels sometimes exceeding those of the retina, strongly suggesting that responses to bright light, which are predominantly mediated by cones, may be present in neonatal pineal. Some rod-specific components, too-such as rhodopsin, rhodopsin kinase, arrestin, and IRBP - also are found in the great majority of pinealocytes, suggesting that pineal phototransduction may use a mixture of rod-specific and cone-specific phototransduction components. This possibility would fit with the normal activation of rodspecific signal transduction components elicited by cone-specific opsins in vitro (Fukuda et al., 1989; Starace and Knox, 1997). Certain other rod and cone-specific phototransduction components, however, are absent from the pineal.

Our findings support other evidence indicating that mammalian pineal glands are physiologically photosensitive in early life (Zweig et al., 1966; Machado et al., 1969a,b; Wetterberg et al., 1970; Torres and Lytle, 1990) and fit with known features of retina and pineal development. The eyes of a rat do not open until the third week of life, so that at earlier stages the pineal gland, which is located quite superficially underneath the very thin neonatal skull, receives more incident light than the retina (Torres and Lytle, 1990). Many of the neurons in the retina that are crucial for phototransduction do not develop until the second to third week of life (Cepko, 1996), whereas pineal cells develop much earlier (Zimmerman and Tso, 1975). Day-night rhythms of NAT and serotonin in the rat pineal are demonstrable and lightsensitive at P2-P4 (Ellison et al., 1972; Yuwiler et al., 1977; Bronstein et al., 1990).

The decline with age in levels of many of the phototransductive elements in the pineal corresponds with the appearance of the sympathetic innervation of the pineal gland. This suggests that sometime at $\sim 2$ weeks of age control of pineal function passes from the light environment to the sympathetic nervous system. Although a number of phototransductive elements remain in the adult pineal, phototransduction has not been demonstrable in the adult pineal. This may relate to the suppression of pineal-like responsivity by the sympathetic innervation as well as to the diminished incident light reaching the pineal gland through the thicker adult skull.

Our finding of abundant blue cone pigment expression in mammalian pineal is striking and contrasts with negligible red cone pigment expression. Why might the pineal prefer blue to red sensitivity? Blue light, which penetrates tissue more poorly than red light (van Brunt et al., 1964; Hartwig and van Veen, 1979), predominates in bright daylight and so may play a role in resetting clock functions in the pineal. Blue cone pigment expression developmentally precedes red (Cepko, 1996), which fits with the earlier development of the pineal than the retina. Interestingly, pinopsin, the opsin of chick pineal, has been shown in biochemical reconstitution experiments to be blue-sensitive (Okano et al., 1994).

In conventional histological staining all pinealocytes appear grossly similar, although there have been suggestions of diversity among pinealocyte populations (Pevet, 1977; Wicht et al., 1993). Our findings argue for functionally diverse pinealocyte populations, because at least six distinct patterns of gene expression for the transcripts tested were observed in both neonatal and adult pinealocytes.

To demonstrate pineal gland phototransduction directly, we have monitored calcium conductance in neonatal rat pineal in organ culture (S. Blackshaw and D. Krautwurst, unpublished data) and have demonstrated cyclic nucleotide-gated calcium conductance. We also have observed light-induced declines in intracellular calcium, which correspond to known patterns of light effects on calcium in the retina. Thus it is likely that the phototransduction elements we have observed mediate physiological light perception in the neonatal pineal gland.

\section{REFERENCES}

Adamus G, Palczewski K, Carruth M, McDowell JH, Hargrave PA (1989) Visual transduction system in the rat pineal gland: evidence for rhodopsin and rhodopsin kinase. Invest Ophthalmol Vis Sci [Suppl] 30:284.

Araki M (1992) Cellular mechanism for norepinephrine suppression of pineal photoreceptor-like cell differentiation in rat pineal cultures. Dev Biol 149:440-447.

Baehr W, Champagne MS, Lee AK, Pittler SJ (1991) Complete cDNA sequences of mouse rod photoreceptor cGMP phosphodiesterase alpha- and beta-subunits and identification of beta', a putative betasubunit isozyme produced by alternative splicing of the beta-subunit gene. FEBS Lett 278:107-114.

Barnstable CJ, Morabito MR (1994) Isolation and coding sequence of the rat rod opsin gene. J Mol Neurosci 5:207-209.

Barr L (1989) Photomechanical coupling in the vertebrate sphincter pupillae. CRC Crit Rev Neurosci 4:325-366.

Blackshaw S, Snyder SH (1997) Parapinopsin, a novel catfish opsin localized to the parapineal organ, defines a new gene family. J Neurosci 17:8083-8092.

Bonigk W, Muller F, Middendorff R, Weyand I, Kaupp UB (1996) Two alternatively spliced forms of the cGMP-gated channel $\alpha$-subunit from cone photoreceptor are expressed in the chick pineal organ. J Neurosci 16:7458-7468.

Brammer M, Binkley S (1981) Pineal glands of immature rats: rise and fall in $N$-acetyltransferase activity in vitro. J Neurobiol 12:167-173.

Bridges CD, Foster RG, Landers RA, Fong SL (1987) Interstitial retinol-binding protein and cellular retinal-binding protein in mammalian pineal. Vision Res 27:2049-2060.

Bronstein DM, Haak KA, Torres G, Lytle LD (1990) Light-induced changes in pineal gland $N$-acetyltransferase: developmental aspects. Neuroendocrinology 51:139-146.

Calvert PD, Klenchin VA, Bownds MD (1995) Rhodopsin kinase inhibition by recoverin. Function of recoverin myristolation. J Biol Chem 270:24127-24129.

Caracamo B, Hurwitz MY, Craft CM, Hurwitz RL (1995) The mammalian pineal expresses the cone but not the rod cyclic GMP phosphodiesterase. J Neurochem 65:1085-1092.

Cepko CL (1996) The patterning and onset of opsin expression in vertebrate retina. Curr Opin Neurol 6:542-546.

Craft CM, Whitmore DH, Donoso LA (1990) Differential expression of mRNA and protein encoding retinal and pineal S-antigen during the light-dark cycle. J Neurochem 55:1461-1473.

Craft CM, Whitmore DH, Wiechmann AF (1994) Cone arrestin identified by targeting expression of a functional family. J Biol Chem 269:4613-4619.

Deguchi T (1982a) Rhodopsin-like photosensitivity of isolated chicken pineal gland. Nature 290:706-707.

Deguchi T (1982b) Sympathetic regulation of circadian rhythm of serotonin $N$-acetyltransferase activity in pineal gland of infant rat. J Neurochem 38:797-802.

Ding C, Potter ED, Qiu W, Coon SL, Levine MA, Guggino SG (1997) Cloning and widespread distribution of the rat rod-type cyclic nucleotide-gated cation channel. Am J Physiol 272:C1335-C1344.

Distler M, Biel M, Flockerzi V, Hofmann F (1994) Expression of cyclic nucleotide-gated cation channels in non-sensory tissues and cells. Neuropharmacology 33:1275-1282.

Dodt E (1963) Photosensitivity of the pineal organ in the teleost, Salmo irideus (Gibbons). Experientia 19:642-643.

Dodt E, Heerd E (1962) Mode of action of pineal nerve fibers in frogs. J Neurophysiol 25:405-429.

Dodt E, Scherer E (1968) Photic responses from the parietal eye of the lizard Lacerta sicula campestris (De Betta). Vision Res 8:61-72.

Eakin RM (1973) The third eye. Berkeley, CA: University of California. 
Ellisson N, Weller J, Klein D (1972) Development of a circadian rhythm in the activity of pineal serotonin $\mathrm{N}$-acetyltransferase. J Neurochem 19:1335-1341.

Foster RG, Timmers AM, Schalken JJ, de Grip WJ (1989) A comparison of some photoreceptor characteristics in the pineal and retina. II. The Djungarian hamster (Phodopus sungorus). J Comp Physiol [A] 165:565-572.

Fukuda Y, Okano T, Artamonov ID, Yoshizawa T (1989) Chicken redsensitive cone visual pigment retains a binding domain for transducin. FEBS Lett 246:69-72.

Hartwig H-G, Oksche A (1982) Neurobiological aspects of extraretinal photoreceptive systems: structure and function. Experientia 38:991-996.

Hartwig H-G, van Veen T (1979) Spectral characteristics of visible radiation penetrating into the brain and stimulating extraretinal photoreceptors. J Comp Physiol [A] 130:277-282.

Ho AK, Somers RL, Klein DC (1986) Development and regulation of rhodopsin kinase in rat pineal and retina. J Neurochem 46:1176-1179.

Huang SK, Klein DC, Korf H-W (1992) Immunocytochemical demonstration of rod-opsin, S-antigen, and neuron-specific properties in the human pineal gland. Cell Tissue Res 267:493-498.

Korf HW (1994) The pineal organ as a component of the biological clock. Phylogenetic and ontogenetic considerations. Ann NY Acad Sci 719:13-42.

Korf H-W, Foster RG, Ekstrom P, Schalken JJ (1985a) Opsin-like immunoreaction in the retinae and pineal organs of four mammalian species. Cell Tissue Res 242:645-648.

Korf H-W, Moller M, Gery I, Zigler JS, Klein DC (1985b) Immunocytochemical demonstration of retinal S-antigen in the pineal organ of four mammalian species. Cell Tissue Res 239:81-85.

Korf H-W, Oksche A, Ekstrom P, Gery I, Zigler JS, Klein DC (1986) Pinealocyte projections into the mammalian brain revealed with Santigen antiserum. Science 231:735-737.

Korf H-W, White BH, Schaad NC, Klein DC (1992) Recoverin in pineal organs of various vertebrate species including man. Brain Res 595:57-66.

Kramm M, de Grip WJ, Korf H-W (1993) Rod-opsin immunoreaction in the pineal organ of the pigmented mouse does not indicate the presence of a functional photopigment. Cell Tissue Res 274:71-78.

Lin AM, Schaad NC, Schulz PE, Coon SL, Klein DC (1994) Pineal nitric oxide synthetase: characteristics, adrenergic regulation, and function. Brain Res 651:160-168.

Machado CRS, Machado ABM, Wragg LE (1969a) Circadian serotonin rhythm control: sympathetic and nonsympathetic pathways in rat pineals of different ages. Endocrinology 85:846-849.

Machado CRS, Wragg LE, Machado ABM (1969b) Circadian rhythm of serotonin in the pineal body of immunosympathectomized immature rats. Science 164:442-443.

Marchiafava PL, Kusmic C (1993) The electrical responses of the trout pineal photoreceptors to brief and prolonged illumination. Prog Brain Res 95:3-13.

Maronde E, Middendorff R, Mayer B, Olcese J (1995) The effect of NO-donors in bovine and rat pineal cells: stimulation of cGMP and cGMP-independent inhibition of melatonin synthesis. J Neuroendocrinol 7:207-214.

Max M, McKinnon PJ, Seidenman KJ, Barrett RK, Applebury ML, Takahashi JS, Margolskee RF (1995) Pineal opsin: a nonvisual opsin expressed in chick pineal. Science 267:1502-1506.

McGinnis JF, Stepanik PL, Baehr W, Subbaraya I, Lerious V (1992) Cloning and sequencing of the $23 \mathrm{kDa}$ mouse photoreceptor cellspecific protein. FEBS Lett 302:172-176.

Meissl H, Samejima M, Morita Y, Dodt E (1982) Intracellular recordings from pineal photoreceptors in the lamprey. Pflügers Arch [Suppl] 394:R62.

Meissl H, Nakamura T, Thiele G (1986) Neural responses in the photoreceptive pineal organ of goldfish. Comp Biochem Physiol [A] 84:467-473.

Menaker M, Keatts H (1968) Extraretinal light perception in the sparrow. II. Photoperiodic stimulation of testes growth. Proc Natl Acad Sci USA 60:146-151.

Menaker M, Roberts R, Elliot J, Underwood H (1970) Extraretinal light perception in the sparrow. III. The eyes do not participate in photoperiodic photoreception. Proc Natl Acad Sci USA 67:320-325.

Milam AH, Dacey DM, Dizhoor AM (1993) Recoverin immunoreactivity in mammalian cone bipolar cells. Vis Neurosci 10:1-12.
Morita Y, Dodt E (1973) Slow photic responses from the isolated pineal organ of lamprey. Nova Acta Leopold 33:331-339.

Morita Y, Segi K, Samejima M, Nakamura T (1985) Intracellular dynamic response characteristics of pineal photoreceptors. Ophthalmic Res 16:119-122.

Morita Y, Samejima M, Tamotsu S (1989) Response patterns and neuronal networks of photosensory pineal organs. Arch Histol Cytol [Suppl] 52:469-475.

Okano T, Yoshizawa T, Fukuda Y (1994) Pinopsin is a chicken pineal photoreceptive molecule. Nature 372:94-97.

Oksche A (1965) Survey of the development and comparative morphology of the pineal organ. Prog Brain Res 10:3-28.

Palczewski K, Carruth ME, Adamus G, McDowell JH, Hargrave PA (1990) Molecular, enzymatic, and functional properties of rhodopsin kinase from rat pineal gland. Vision Res 30:1129-1137.

Pepperberg DR, Okajima TL, Wiggert B, Ripps H, Crouch RK, Chader GJ (1993) Interphotoreceptor retinoid-binding protein (IRBP). Molecular biology and physiological role in the visual cycle of rhodopsin. Mol Neurobiol 7:61-85.

Pevet P (1977) On the presence of different populations of pinealocytes in the mammalian pineal gland. J Neural Transm 40:289-304.

Raport CJ, Dere B, Hurley JB (1989) Characterization of the mouse rod transducin alpha-subunit gene. J Biol Chem 264:7122-7128.

Reppert SM, Coleman RJ, Heath HW, Swedlow JR (1984) Pineal $N$ acetyltransferase activity in 10-day-old rats: a paradigm for studying the developing circadian system. Endocrinology 115:918-925.

Rodrigues MM, Hackett J, Gaskins R, Wiggert B, Lee L, Redmond M, Chader GJ (1986) Interphotoreceptor retinoid-binding protein in retinal rod cells and pineal gland. Invest Ophthalmol Vis Sci 27:844-850.

Sakai T (1981) The mammalian Harderian gland: morphology, biochemistry, function, and phylogeny. Arch Histol Jpn 44:299-333.

Schaeren-Wiemers N, Gerfin-Moser A (1993) A single protocol to detect transcripts of various types and expression levels in neural tissue and culture cells: in situ hybridization using digoxygenin-labeled probes. Histochemistry 100:431-440.

Solessio E, Engbretson GA (1993) Antagonistic chromatic mechanisms in photoreceptors of the parietal eye of lizards. Nature 364:442-445.

Sommers RL, Klein DC (1984) Rhodopsin kinase activity in the mammalian pineal gland and other tissues. Science 226:182-184.

Spessert R (1993) Vasoactive intestinal peptide stimulation of cyclic guanosine monophosphate formation: further evidence for a role of nitric oxide synthase and cytosolic guanylate cyclase in rat pinealocytes. Endocrinology 132:2513-2517.

Starace DM, Knox BE (1997) Activation of transducin by a Xenopus short wavelength visual pigment. J Biol Chem 272:1095-1100.

Tabata M, Tamura T, Niwa H (1975) Origin of the slow potential in the pineal organ of rainbow trout. Vision Res 15:737-740.

Torres G, Lytle LD (1990) Light affects neonatal rat pineal gland $N$ acetyltransferase activity by an extraretinal mechanism. J Neural Transm 80:67-77.

Ulrich R, Yuwiler A, Wetterberg L, Klein D (1973) Effects of light and temperature on the pineal gland in newborn rats. Neuroendocrinology 13:255-263.

van Brunt EE, Shepherd MD, Wale RJ, Ganong WF, Clegg M-T (1964) Penetration of light into the brain of mammals. Ann NY Acad Sci 117:217-224.

van Veen T, Ostholm T, Gierschik P, Spiegel A, Somers R, Korf H-W, Klein DC (1986a) $\alpha$-Transducin immunoreactivity in retinae and sensory pineal organs of adult vertebrates. Proc Natl Acad Sci USA 83:912-916.

van Veen T, Katial A, Shinohara T, Barrett DJ, Wiggert B, Chader GJ, Nickerson JM (1986b) Retinal photoreceptor neurons and pinealocytes accumulate mRNA for interphotoreceptor retinoid-binding protein (IRBP). FEBS Lett 209:133-137.

Viczian AS, Piriev NI, Farber DB (1995) Isolation and characterization of a cDNA encoding the alpha subunit of human cone cGMPphosphodiesterase. Gene 166:205-211.

Vigh-Teichmann I, Vigh B, Gery I, van Veen T (1986) Different types of pinealocytes as revealed by immunoelectron microscopy of anti-Santigen and antiopsin binding sites in the pineal organ of frog, toad, hedgehog, and bat. Exp Biol 45:27-43.

Weber W (1983) Photosensitivity of chromatophores. Am Zool 23:495-506.

Wei JY, Cohen ED, Yan YY, Genieser HG, Barnstable CJ (1996) Identification of competitive antagonists of the rod photoreceptor 
cGMP-gated cation channel: $\beta$-phenyl-1,N2-etheno-substituted cGMP analogues as probes of the cGMP-binding site. Biochemistry 35:16815-16823.

Wetterberg L, Geller E, Yuwiler A (1970) The mammalian Harderian gland: an extraretinal photoreceptor in neonatal rats? Science 167:884-885.

Wicht H, Korf H-W, Schaad NC (1993) Morphological and immunocytochemical heterogeneity of cultured pinealocytes from one-week- and two-month-old rats: planimetric and densitometric investigations. J Pineal Res 14:128-137.

Wurtman RJ, Axelrod J, Kelly DE (1968) The pineal. New York: Academic.

Yang RB, Foster DC, Garbers DL, Fulle H-J (1995) Two membrane forms of the guanylyl cyclase found in the eye. Proc Natl Acad Sci USA 92:602-606.

Yu WP, Grunwald ME, Yau K-W (1996) Molecular cloning, functional expression, and chromosomal localization of a human homolog of the cyclic nucleotide-gated ion channel of retinal cone photoreceptors. FEBS Lett 393:211-215.

Yuwiler A, Klein D, Buda M, Weller J (1977) Adrenergic control of pineal $N$-acetyltransferase activity: developmental aspects. Am J Physiol 233:E141-E146.

Zhao X, Haeseleer F, Fariss RN, Huang JN, Baehr W, Milam AH, Palczewski K (1997) The molecular cloning and localization of rhodopsin kinase in the mammalian pineal. Vis Neurosci 14:225-232.

Zigman JM, Westermark GT, LaMendola J, Steiner DF (1994) Expression of cone transducin, $G_{z \alpha}$, and other G-protein alpha-subunit messenger ribonucleic acids in pancreatic islets. Endocrinology 135:31-37.

Zimmerman BL, Tso MO (1975) Morphological evidence of photoreceptor differentiation of pinealocytes of neonatal rat. J Cell Biol 66:60-75.

Zweig M, Snyder SH, Axelrod J (1966) Evidence for a nonretinal pathway of light to the pineal gland of newborn rats. Proc Natl Acad Sci USA 56:515-520. 